\title{
Developing primary health care and public health competencies in undergraduate medical students
}

\author{
Stephen E Knight ${ }^{a}$, Andrew J Ross ${ }^{\text {a* }}$ and Ozayr Mahomed ${ }^{a}$ \\ aSchool of Nursing and Public Health, College of Health Sciences, University of KwaZulu-Natal, Durban, South Africa \\ *Corresponding author, email: rossa@ukzn.ac.za
}

\begin{abstract}
Background: The Selective Programme (Selectives) at the University of KwaZulu-Natal (UKZN) is a three-year longitudinal, community-based programme within the undergraduate medical curriculum, which aims to develop primary health care (PHC) and public health competencies in students using the community-oriented primary care (COPC) approach.

Aim: The aim of this research was to evaluate the Selectives against the Health Professions Council of South Africa (HPCSA) 'core' graduate competencies.

Setting: This study was carried out among medical students concluding Selectives at UKZN in 2015.

Methods: A cohort of 183 students concluded Selectives in 2015, and thereafter 70 (38\%) completed a routine online evaluation of the programme based on the core graduate competencies.

Results: Students reported substantial improvements in PHC clinical knowledge, improved understanding of a population perspective on health, and having gained public health knowledge and skills.

Conclusion: Selectives is an effective way to use a decentralised PHC learning platform to enable medical students to address some of the HPCSA graduate competencies required for health care professionals and not necessarily covered by other medical disciplines.
\end{abstract}

Keywords: community-based curriculum, community engagement, community-oriented primary care, KwaZulu-Natal, research training

\begin{abstract}
Introduction
South Africa faces a quadruple burden of disease and other critical health system challenges. Dealing with these issues requires healthcare professionals (HCPs) to be clinically competent transformational agents able to work in cooperation with other HCPs and stakeholders to address health system deficiencies and social determinants of health. ${ }^{1,2}$ In order to ensure appropriate training of HCPs the Health Professions Council of South Africa (HPCSA) requires medical school curricula and learning to be aligned to 'core' graduate competencies (Figure 1), so that millennial graduates are skilled clinicians able to provide professional and ethical health care that is needed by the whole population. ${ }^{3}$
\end{abstract}

These core competencies are consistent with three other global educational imperatives, namely improving medical students' understanding of a population health approach; ${ }^{1,2}$ ensuring students appreciate the 'upstream' or social determinants of health and disease; ${ }^{1,5}$ and improving their research capacity and ability to be reflective learners. ${ }^{1,6-8}$ The challenge for educators is to inculcate in medical students a population-based approach to health care, an understanding of the social determinants of health and an ethos of research scholarship, when most of the curriculum is biomedically focused. ${ }^{9}$ In addition, educators need to ensure that these educational imperatives enable students to become socially responsive and accountable change agents in the ailing healthcare system. ${ }^{10,11}$

The Selective Programme (Selectives) in Nelson R Mandela School of Medicine at the University of KwaZulu-Natal (UKZN) comprises three four-week modules in the second, third and fourth academic years of the six-year undergraduate medical curriculum. Selectives is an innovative longitudinal, community-based educational initiative built around the principles of community-orientated primary care (COPC), which integrates primary health care $(\mathrm{PHC})$, clinical care and a population perspective using public health knowledge and skills (Figure 2). ${ }^{12,13}$

At the start of Selectives 1, second-year medical students who come from five provinces in South Africa and Lesotho choose a defined community close to their home where they can experience clinical PHC and make a community diagnosis in a decentralised teaching platform. ${ }^{15}$ At these sites students engage the community through patients at the PHC level, and move from a focus on sick patients to a population-based and public health perspective. The Selectives site facilitator is a PHC practitioner who is not part of the medical school teaching staff. ${ }^{16}$

Students progress from observing patient care in $\mathrm{PHC}$ facilities in Selectives 1 (second year) to participating in patient care in Selectives 2 and 3 (third and fourth year respectively). In addition, in Selectives 1 they evaluate PHC services, identify the range of $\mathrm{PHC}$ resources available in the community, and develop their understanding of evidence-based medicine. In Selectives 2 each group conducts a community-based survey to quantify a need previously identified in the community. ${ }^{17}$ The research findings inform each group when implementing their health-promotion activity in Selectives 3, which closes the COPC cycle. ${ }^{3}$ Students also experience a home visit to the same family each year for the three years of their Selectives.

The prescribed learning outcomes address many aspects of the HPCSA core competencies as well as the three educational imperatives (Table 1). The design, coordination, delivery and 


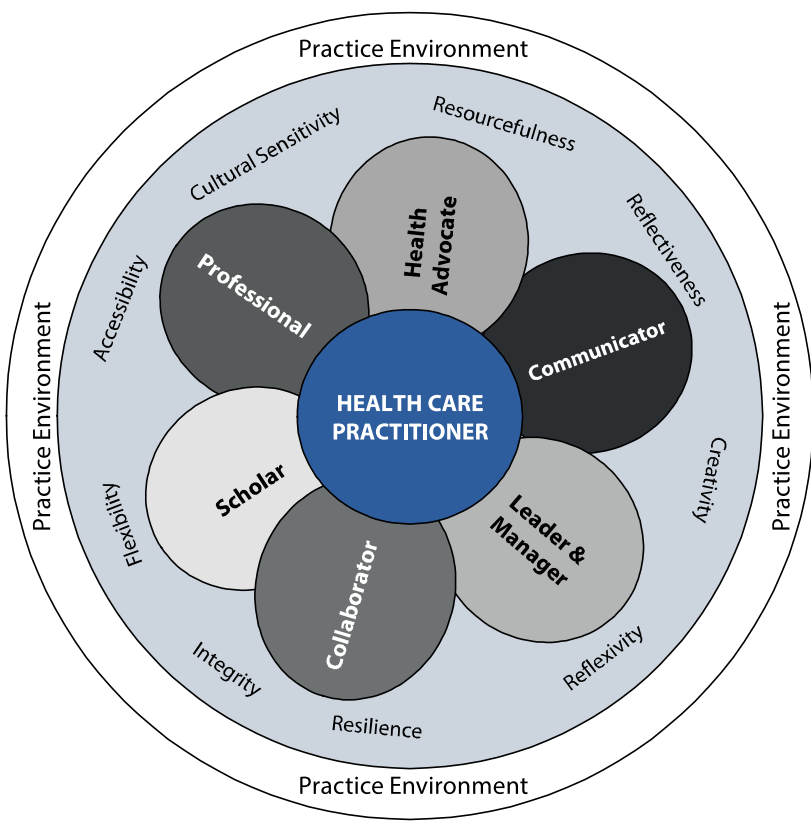

Figure 1: Core graduate competencies for Health Care Professionals at UKZN.

Source: Adapted from the HPCSA Core Competencies for Undergraduate Programmes in South Africa (2014) with permission of the HPCSA Undergraduate Committee obtained March 2014. ${ }^{4}$

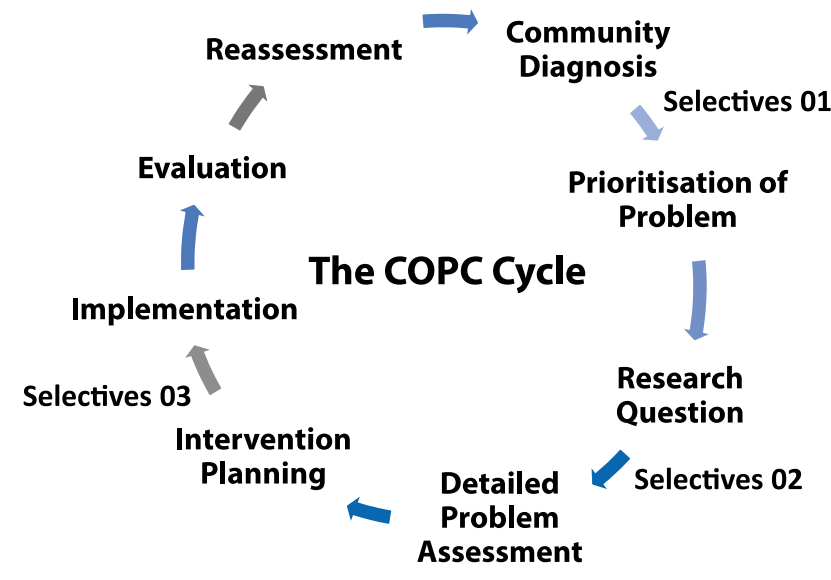

Figure 2: Community Oriented Primary Care cycle and its relationship to the Selectives Programme.

Source: Adapted from Kark and Kark. ${ }^{14}$

assessments of students in the Selectives module is the collective responsibility of academics from the Family Medicine, Public Health Medicine and Rural Health disciplines. Successful completion of these modules is a prerequisite for graduating from the medical programme.

Selectives offer medical students at UKZN authentic early exposure to PHC clinical care and community health issues. ${ }^{19}$ The programme is designed to ensure community engagement (rather than community tourism) and enhance student understanding of $\mathrm{PHC} .{ }^{12}$ Students gain clinical acumen by spiral learning from a range of PHC practitioners in their 'home' communities. Both clinical and public health assignments assist students' learning and enable engagement with individuals, communities and health facilities in a structured manner; this helps them gain a population perspective of health and better understand social determinants of health within the community. ${ }^{20}$ Experiential, transformational learning therefore occurs in authentic community settings.

In moving from the traditional disease-focused approach, the COPC model enables students to appreciate and respond to the social determinants of health, recognise community needs and learn how PHC interventions can be measured using epidemiological principles as well as the value of working with multidisciplinary teams. Selectives also enable students to gain insight into the proactive role of PHC providers as stakeholders in integrated preventative, promotive and curative services.

Although learning about many of the core competencies expected of medical graduates by the HPCSA is included in Selectives, the programme has never been formally evaluated. The aim of this study was to evaluate students' perception of the extent to which the core graduate competencies are met by the Selectives at UKZN.

\section{Research methods and design}

An observational descriptive case-study design was used. All medical students concluding Selectives in 2015 were encouraged to complete an anonymised online questionnaire. The questionnaire was custom developed to enable students to reflect on: their experiences during the Selectives blocks in a PHC setting; their learning about $\mathrm{PHC}$ and a population perspective; their public health knowledge and skills developed through the Selectives assignments.

Both quantitative (closed-ended questions) and qualitative (open-ended questions) data were collected, which covered the six core competencies from the HPCSA framework (see Table 1). The questionnaire used a three-point Likert scale to quantify students' responses, which were categorised as 'Agree', 'Neither agree nor disagree' and 'Disagree'. The qualitative data were analysed thematically to determine students' experience and learning with reference to the core competencies.

Ethical approval for the ongoing evaluation of the Selectives was sought and obtained from the Biomedical Research Ethics Committee of UKZN (R201/04).

\section{Results}

A cohort of 183 medical students completed all the requirements of the three Selectives modules in 2015 . Seventy (38\%) students voluntarily completed the online Selectives evaluation questionnaire. The majority of students were young (mean age 22 years), Black African (70\%) with $62 \%$ of the cohort being female. Students were from areas self- categorised as rural (37\%), peri-urban or township (27\%) and urban (36\%). The areas where they chose to conduct their Selectives closely reflected the locations of their homes (39\% rural, 29\% peri-urban and 32\% urban). This is supported by the fact that $83 \%$ of the class indicated that they had slept at home during the Selectives period, compared with $29 \%$ who normally sleep at home during the term.

The majority $(58,83 \%)$ of students expressed appreciation of the learning platform provided in community-based sites, and found this PHC platform to be conducive to learning. Students reported that the experiential learning at these PHC sites provided opportunities to understand the role of various $\mathrm{PHC}$ practitioners, perform $\mathrm{PHC}$ consultations, gain a population perspective on health, and begin to develop an understanding of the South 
Table 1: Selectives Programme outcomes aligned to HPCSA graduate 'core competencies'

\begin{tabular}{|c|c|}
\hline HPCSA core competencies & $\begin{array}{l}\text { Selectives health practitioner } \\
\text { outcomes }\end{array}$ \\
\hline \multicolumn{2}{|l|}{ Expert health practitioner } \\
\hline \multirow{4}{*}{$\begin{array}{l}\text { Establish and maintain knowledge, } \\
\text { skills, attitudes and character appro- } \\
\text { priate to their practice }\end{array}$} & $\begin{array}{l}\text { Record } 20 \text { observed PHC consultation } \\
\text { (Selectives } 1 \text { ) }\end{array}$ \\
\hline & $\begin{array}{l}\text { Participate in } 10 \text { PHC consultations } \\
\text { and record in SOAP (S: subjective, } \\
\text { O: objective, A: assessment, P: plan) } \\
\text { format (Selectives 2) }\end{array}$ \\
\hline & $\begin{array}{l}\text { Critically reflect on } 5 \text { PHC consulta- } \\
\text { tions (Selectives } 3 \text { ) }\end{array}$ \\
\hline & $\begin{array}{l}\text { Follow up a patient with non-com- } \\
\text { municable disease at home over } \\
3 \text { years }\end{array}$ \\
\hline $\begin{array}{l}\text { Perform a comprehensive assessment } \\
\text { of a patient }\end{array}$ & $\begin{array}{l}\text { Prepare case reports on patients with } \\
\text { a chronic and acute medical problem } \\
\text { in context }\end{array}$ \\
\hline $\begin{array}{l}\text { Use preventive, promotive, therapeu- } \\
\text { tic and rehabilitative interventions } \\
\text { effectively }\end{array}$ & $\begin{array}{l}\text { Record an assessment and } \\
\text { intervention plan for a number of } \\
\text { primary-level diagnoses using Stand- } \\
\text { ard Treatment Guidelines \& Essential } \\
\text { Medicines List }{ }^{18}\end{array}$ \\
\hline \multirow{2}{*}{$\begin{array}{l}\text { Seek appropriate consultation from } \\
\text { other HCPs, recognising the limits of } \\
\text { their own and others' expertise }\end{array}$} & $\begin{array}{l}\text { Four group meetings with Selectives } \\
\text { supervisor (medical school teacher) } \\
\text { per year x } 3\end{array}$ \\
\hline & $\begin{array}{l}\text { Structured reflective learning } \\
\text { assignments with spiral learning in } \\
\text { each year }\end{array}$ \\
\hline Communication & Selectives communication outcomes \\
\hline \multirow{7}{*}{$\begin{array}{l}\text { As communicators healthcare practi- } \\
\text { tioners effectively facilitate the carer- } \\
\text { patient relationship and the dynamic } \\
\text { exchanges that occur before, during } \\
\text { and after the intervention }\end{array}$} & $\begin{array}{l}\text { Write portfolios of evidence that are } \\
\text { submitted electronically }\end{array}$ \\
\hline & $\begin{array}{l}\text { Process and present data as a 'prac- } \\
\text { tice profile' }\end{array}$ \\
\hline & $\begin{array}{l}\text { Prepare a study protocol for biomedi- } \\
\text { cal ethical review }\end{array}$ \\
\hline & $\begin{array}{l}\text { Prepare and present a scientific } \\
\text { research poster }\end{array}$ \\
\hline & $\begin{array}{l}\text { Conduct a health-promotion inter- } \\
\text { vention }\end{array}$ \\
\hline & $\begin{array}{l}\text { Group presentation of the } \\
\text { health-promotion intervention and } \\
\text { evaluation as PowerPoint }{ }^{\oplus} \text { slides to } \\
\text { peers and examiners }\end{array}$ \\
\hline & $\begin{array}{l}\text { Learn to communicate across lan- } \\
\text { guage barriers. }\end{array}$ \\
\hline Collaboration & Selectives collaboration outcomes \\
\hline \multirow{6}{*}{$\begin{array}{l}\text { As collaborators, healthcare practi- } \\
\text { tioners work effectively within a team } \\
\text { to achieve optimal patient care }\end{array}$} & $\begin{array}{l}\text { Work with peers in a Selectives group } \\
\text { over } 3 \text { years }\end{array}$ \\
\hline & Learn and work with a site facilitator \\
\hline & $\begin{array}{l}\text { Describe and map PHC resources in } \\
\text { the Selectives site }\end{array}$ \\
\hline & $\begin{array}{l}\text { Visit homes with community health } \\
\text { workers/ward-based outreach teams }\end{array}$ \\
\hline & $\begin{array}{l}\text { Work in and learn } \mathrm{PHC} \text { in clinics with } \\
\text { a range of } \mathrm{PHC} \text { practitioners }\end{array}$ \\
\hline & $\begin{array}{l}\text { Collaborate with local non-govern- } \\
\text { ment organisation }\end{array}$ \\
\hline
\end{tabular}

Table 1: (Continued)

\begin{tabular}{|c|c|}
\hline HPCSA core competencies & $\begin{array}{l}\text { Selectives health practitioner } \\
\text { outcomes }\end{array}$ \\
\hline Management \& Leadership & $\begin{array}{l}\text { Selectives management \& leadership } \\
\text { outcomes }\end{array}$ \\
\hline \multirow{5}{*}{$\begin{array}{l}\text { As managers, healthcare practitioners } \\
\text { are integral participants in healthcare } \\
\text { organisations, organising sustain- } \\
\text { able practices, making decisions } \\
\text { about allocating resources, and } \\
\text { contributing to the effectiveness of } \\
\text { the healthcare system }\end{array}$} & $\begin{array}{l}\text { Students select their own groups, } \\
\text { identify a site facilitator and organise } \\
\text { their own Selectives site }\end{array}$ \\
\hline & $\begin{array}{l}\text { Manage own time and learning } \\
\text { during Selectives }\end{array}$ \\
\hline & Appreciate professional diversity \\
\hline & $\begin{array}{l}\text { Work and learn from the interprofes- } \\
\text { sional PHC team }\end{array}$ \\
\hline & Conduct a prescription review \\
\hline Health advocacy & Selectives health advocacy outcomes \\
\hline $\begin{array}{l}\text { As health advocates, healthcare } \\
\text { practitioners responsibly use their ex- } \\
\text { pertise and influence to advance the } \\
\text { health and well-being of individuals, } \\
\text { communities and populations }\end{array}$ & $\begin{array}{l}\text { Conduct repeat home visits over } \\
3 \text { years } \\
\text { Implement a health-promotion } \\
\text { activity informed by research findings }\end{array}$ \\
\hline Scholarship & Selectives scholarship outcomes \\
\hline \multirow{14}{*}{$\begin{array}{l}\text { As scholars, healthcare practitioners } \\
\text { demonstrate a lifelong commitment } \\
\text { to reflective learning, as well as the } \\
\text { creation, dissemination, application } \\
\text { and translation of knowledge }\end{array}$} & $\begin{array}{l}\text { Formulate a research question (based } \\
\text { on a practice profile and community } \\
\text { diagnosis) in a PHC setting }\end{array}$ \\
\hline & Conduct a literature review \\
\hline & Prepare a research protocol \\
\hline & Complete an online ethics certificate \\
\hline & Prepare a questionnaire \\
\hline & $\begin{array}{l}\text { Obtain ethical approval from Biomed- } \\
\text { ical Research Ethics Committee }\end{array}$ \\
\hline & $\begin{array}{l}\text { Conduct fieldwork with informed } \\
\text { consent }\end{array}$ \\
\hline & Process descriptive data \\
\hline & Prepare a scientific research poster \\
\hline & $\begin{array}{l}\text { Present poster to peers and examin- } \\
\text { ers at a'poster day' }\end{array}$ \\
\hline & $\begin{array}{l}\text { Prepare health-promotion interven- } \\
\text { tion informed by research findings }\end{array}$ \\
\hline & $\begin{array}{l}\text { Implement and evaluate the inter- } \\
\text { vention }\end{array}$ \\
\hline & $\begin{array}{l}\text { Reflective learning assignments in } \\
\text { each year: }\end{array}$ \\
\hline & $\begin{array}{l}\text { - Meaning of disease } \\
\text { - Personal experience of medical } \\
\text { consultations } \\
\text { - Exit from home visits after } \\
3 \text { years }\end{array}$ \\
\hline Professional & Selectives professional outcomes \\
\hline \multirow{5}{*}{$\begin{array}{l}\text { As professionals healthcare practi- } \\
\text { tioners are committed to ensure the } \\
\text { health and well-being of individuals } \\
\text { and communities through ethical } \\
\text { practice, profession-led self-regula- } \\
\text { tion and high personal standards of } \\
\text { behaviour }\end{array}$} & Obtain an online bioethics certificate \\
\hline & $\begin{array}{l}\text { Submit protocol for institutional } \\
\text { ethics review }\end{array}$ \\
\hline & $\begin{array}{l}\text { Prepare consent form and participant } \\
\text { information sheet }\end{array}$ \\
\hline & Get 'gatekeeper' permissions \\
\hline & Upload assignments on time \\
\hline
\end{tabular}




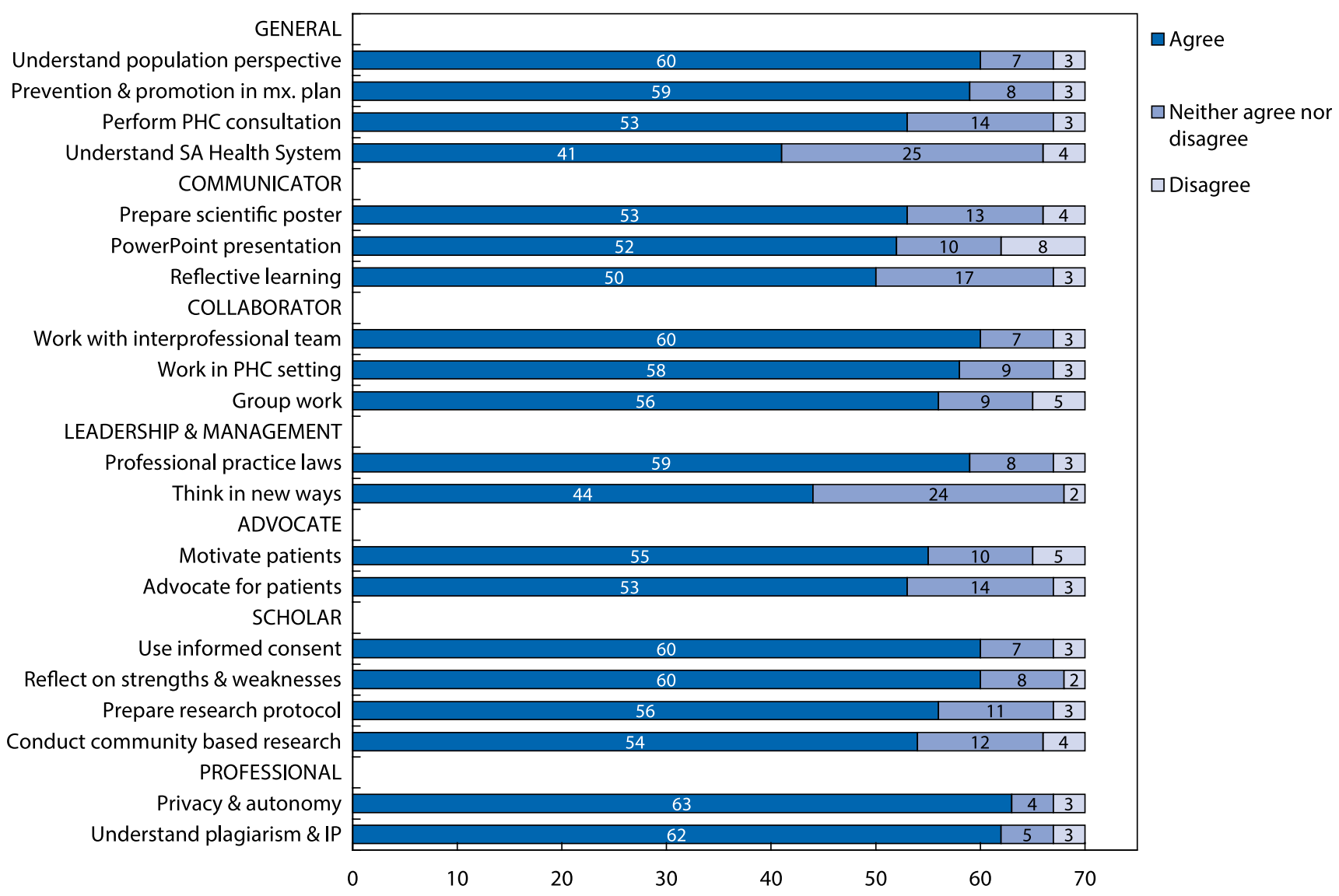

Figure 3: Responses of medical students $(n=70)$ to statements about a population health approach and public health knowledge and skills reflected in HPCSA 'core competencies' and gained from the Selectives Programme at UKZN, 2015.

African health system (Figure 3). The knowledge and skills gained in the Selectives addresses many of the HPCSA core graduate attributes.

In addition, the majority of students reported that the prescribed tasks improved their communication skills as they presented research findings in a scientific poster $(53,76 \%)$, delivered PowerPoint ${ }^{\circledR}$ presentations $(52,74 \%)$ and prepared written learning portfolios.

Students appreciated the opportunity of working in collaboration with members of the interprofessional PHC team. They also valued feedback from peers and other health workers when working together as groups, a process that they found to be supportive of their learning.

In terms of leadership and management, students reported that Selectives helped them to developed generic skills including time management, teamwork, self-directed learning and the use and application of information technology. In addition, students said they learnt to think in new ways during the Selectives.

Selectives highlighted for them the important role that graduate professionals can play as health advocates. They reported that the authentic PHC consultations contributed to their learning how to motivate behaviour change in individual patients. In addition, building on their community research they indicated that they gained skills as health advocates as they prepared and implemented the health-promotion intervention plan in their chosen community.
With regard to scholarship, the majority $(54,77 \%)$ of students reported that the Selectives experience allowed them opportunities to learn about research and to gain practical research skills. They reported having a better understanding of both research methods and the research process, as well as of descriptive epidemiology and biostatistics. They also stated that they had an increased awareness of plagiarism, intellectual property, ethics and study participant confidentiality.

In addition, students reported developing skills in accessing and appraising literature relevant to their research topics; processing and analysing data; and writing and presenting evidence-based reports. Students reported that the research project and other tasks required them to learn and apply clinical epidemiology while gathering authentic patient information to measure their identified research question. Reflective learning capability was also reported to have improved.

Qualitative comments attest to students' learning in the six core competencies, as presented in Table 2.

\section{Discussion}

The Selective Programme has become an integral part of the undergraduate medical curriculum in the second, third and fourth academic years at UKZN. A unique feature of this programme is the location of the Selectives within the home community of the student. Most students (83\%) live at home during their Selectives, thus enabling them to experience PHC in a familiar setting. In addition, two-thirds of students conducted their Selectives in sites situated in rural or disadvantaged communities, thus 
Table 2: Medical students' (sex, age and Selectives site) comments about their experiences in the Selectives categorised according to the HPCSA core competencies

\begin{tabular}{|c|c|}
\hline \multirow{8}{*}{ Expert health practitioner } & $\begin{array}{l}\text { 'Participating in the consultations was good, that is where I got my first clinical exposure' (Male, } \\
23 \text { years, rural township) }\end{array}$ \\
\hline & $\begin{array}{l}\text { 'I enjoyed being able to practise at a PHC level in the consultation of the patients' (Male, } 23 \text { years, rural } \\
\text { township) }\end{array}$ \\
\hline & $\begin{array}{l}\text { [l learnt from] 'identifying a chronic patient (a neonate) which I followed up for three years' (Female, 24+ } \\
\text { years old, rural area) }\end{array}$ \\
\hline & $\begin{array}{l}\text { 'I enjoyed the integration of theory of medicine into practical aspect. Using a patient-centred approach } \\
\text { was useful to gain rapport, insight and perspective about diseases and how they impact on our pa- } \\
\text { tients' (Female, } 21 \text { years, city suburb) }\end{array}$ \\
\hline & $\begin{array}{l}\text { [Doing home visits] 'gave me an in-depth understanding of environmental, social, economic and cultur- } \\
\text { al determinants of health' (Male, 24+ years old, rural area) }\end{array}$ \\
\hline & $\begin{array}{l}\text { [Selectives] 'helped me to acknowledge that a patient is more than a bunch of symptoms put together } \\
\text { to form a diagnosis. There is a psychological and physical and emotional aspect as well' (Female, } \\
22 \text { years, city suburb) }\end{array}$ \\
\hline & $\begin{array}{l}\text { 'I enjoyed that we were able to go into the communities and learn through experience in a non-threat- } \\
\text { ening environment where there was no pressure to perform as is experienced in the hospital setting' } \\
\text { (Female, } 22 \text { years, small town) }\end{array}$ \\
\hline & $\begin{array}{l}\text { 'The home visit was a highlight for me and I was always looking forward to because I got an oppor- } \\
\text { tunity to see how a disease impacts the family and how can the family get involved in managing the } \\
\text { disease' (Male, } 22 \text { years, city centre) }\end{array}$ \\
\hline \multirow{3}{*}{ Communicator } & 'I was able to improve in my communication skills' (Female, 24+ years, rural area) \\
\hline & $\begin{array}{l}\text { [Selectives] 'enabled me to share my knowledge with members of my community' (Female, } 22 \text { years, } \\
\text { small town) }\end{array}$ \\
\hline & $\begin{array}{l}\text { [The] community health promotion was awesome, beautiful feeling ever to be in touch with the com- } \\
\text { munity and to share the knowledge that I have acquired thus far' (Male, 24+ years, small town) }\end{array}$ \\
\hline \multirow{3}{*}{ Collaborator } & $\begin{array}{l}\text { [Selectives] 'helped me to better understand my role as a health care in the community I grew up in' } \\
\text { (Male, } 20 \text { years, rural area) }\end{array}$ \\
\hline & $\begin{array}{l}\text { 'Working in my community and gaining knowledge about the health problems experienced' (Female, } \\
22 \text { years, township) }\end{array}$ \\
\hline & 'I enjoyed interacting with other members of the healthcare team' (Male, 22 years, city centre) \\
\hline \multirow{3}{*}{ Health advocate } & 'The [health promotion] intervention — I felt like we made a difference' (Female, 22 years, small town) \\
\hline & 'I enjoyed the health promotion intervention' (Female, 22 years, small town \\
\hline & $\begin{array}{l}\text { 'I felt that Selectives gave me a sense of accomplishment in terms of the health intervention, as it } \\
\text { highlighted that I am able to make a difference in the community even in the simplest way ... in our } \\
\text { communities' (Male, } 21 \text { years, rural township) }\end{array}$ \\
\hline \multirow{3}{*}{ Scholarship } & $\begin{array}{l}\text { 'Selectives has given us abilities and skills in research that we would have not gained anywhere else in } \\
\text { our medical curriculum' (Female, } 21 \text { years, city suburb) }\end{array}$ \\
\hline & $\begin{array}{l}\text { [Reflective practice] helped me to reflect on myself as a clinician and how I can better myself as an } \\
\text { individual when dealing with patients' (Female, } 21 \text { years, rural township) }\end{array}$ \\
\hline & $\begin{array}{l}\text { 'I enjoyed the use of the Gibbs reflective cycle - it gave me a holistic knowledge on how to approach } \\
\text { situations of a similar nature differently; it also gave itself to self-reflection' (Female, } 21 \text { years, rural area) }\end{array}$ \\
\hline
\end{tabular}

supporting the goal to encourage and advance health professional education and training in decentralised rural training sites.

Positive clinical and educational experiences in rural settings or underserved areas as part of undergraduate medical education are reported to be one of the best predictors of graduates choosing to work in such areas. Selectives may thus be enabling UKZN to advance their social accountability agenda of training for the needs of this country, with (hopefully) a greater number of graduates choosing to work in rural and underserved areas in South Africa in the future. ${ }^{21,22}$ Whether they ultimately choose to work in these marginalised communities, Selectives will to some extent prepare them for the compulsory community service that all health professionals need to complete before being able to register in this country.
Students reported that the Selectives improved their clinical skills, as they learnt from a variety of HCPs through exposure in a PHC setting. They also reported an increased understanding of their professional roles and responsibilities, learnt from observing and working with other HCPs in the various PHC sites.

Students reported that the Selectives improved their communication skills with patients and colleagues. This is consistent with other reported findings, where early exposure to clinical care helped students learn about the importance of good doctor-patient relationships and improved their communication skills. ${ }^{23,24}$ Early clinical exposure has also been shown to increase students' understanding of what it means to work as an $\mathrm{HCP}$, their clinical confidence and competence, as well as their motivation to master preclinical theoretical content. ${ }^{25}$ 
In addition, early clinical exposure has the potential to enrich the curriculum, as exposure to authentic clinical settings encourages an orientation towards the needs of society, which can have a formative influence on students choosing more socially responsive careers. ${ }^{19}$

In this study students reported that their engagement with authentic experiences at PHC facilities, in homes and in the community increased their understanding of health systems. The COPC approach enabled them to move from clinic-based PHC to learning about a population perspective, and helped them to develop public health knowledge and skills. Through the various assignments and engaging in the extended learning platform provided through the community engagement, students reported that they developed self-reliance, teamwork and collaboration as they learnt to work with other members of the PHC team, communication and interpersonal skills, as well as scholarship and research skills.

In addition, the extended learning platform facilitated the formation of long-term relationships with their peers and community members and helped them gain a deeper understanding of the health needs of a population, the healthcare system and its responsiveness to community health needs. Other studies have shown that early clinical exposure helps students develop these 'soft' skills, which are essential for the practice of medicine in the twenty-first century. ${ }^{25}$

In keeping with other studies, students recognised the benefits and value of their research experience gained during their Selectives, which exposed them to translational research in a manner that was inseparable from patient contact and clinical care. ${ }^{26-29,30,31}$ This experience was formative for the UKZN students as it also influenced subsequent health-promotion interventions planned by the students. The health-intervention projects allowed students to develop communication, advocacy and collaborative skills as they worked with other members of the PHC team to address issues identified in their community diagnosis and research. By using the research findings as the basis for their health-promotion intervention plan, the medical students learnt to be responsive to the needs of local communities, and to be socially accountable and transformative agents. ${ }^{1}$

Following completion of the Selectives, students perceived themselves as more experienced in information retrieval and writing skills, important skills in an era of evidenced-based medicine. The Selectives thus provided an authentic and useful research experience, while responding to the challenge of including research training in the design of the modern medical curriculum. Other studies suggest that early exposure of medical students to practical research activities improves their attitudes towards research and scholarship. In addition, research experience during training has been linked to medical graduates pursuing research-related careers and becoming physician scientists, which promotes scientific output. ${ }^{32-34}$ In addition, improved research capacity and use of evidence-based approaches for decision-making acquired by Selectives students should result in better clinical care, safety and competency.

These benefits justify the integration of research teaching into medical curricula in order to improve patient care. ${ }^{30}$ In the absence of literature describing other innovative ways to engage students in population-based primary care research, it is hoped that this study will encourage health professions educators in similar resource-constrained settings to explore innovate ways to make research meaningful and relevant.

In addition, locating population-based learning within PHC settings advances the social accountability agenda, as these students are equipped to conduct patient-based studies. ${ }^{35}$ There are, however, limited descriptions of innovative ways to engage students in 'real-life' population-based PHC experiences, and even fewer that link research training to a community-based academic programme.

The internal validity of this study is limited by selection and information bias. Only 70 (38\%) students completed the end-ofprogramme online evaluation. Although anonymised the data may reflect a social desirability bias.

\section{Challenges}

There are challenges in securing adequate numbers of suitably trained faculty supervisors to guide the groups. Due to the bulky nature of medical curricula and the off-site location of research, groups and supervisors complained of time pressures to prepare the research protocols and posters within short deadlines. The majority of students accepted on the medical programme are first-time tertiary education entrants with limited prior research exposure, and many are English secondlanguage users. For some these barriers affect the quality of their research outputs.

\section{Conclusion}

The Selective Programme is an innovative and effective curricular way to extend the learning platform. It allows for the incorporation of PHC teaching and research training as well as creating a greater awareness of 'upstream' health factors, at minimal cost to the faculty, utilising the COPC approach. Selectives facilitated learning for the majority of the cohort, enabled students to gain clinical, communicative and collaborative skills, increased their understanding of local needs, and exposed them to their advocacy role as possible change agents for the community. Many of the HPCSA 'core competencies' for healthcare practitioners are addressed by the Selectives experience and by students' completion of the required assignments.

Selectives at UKZN has evolved into the current format over the last decade. There is, however, a need for a more systematic process to benchmark students' gain in PHC skills, a population perspective and public health knowledge and skills. Further research with communities and healthcare workers at clinics will help us understand the extent to which the Selectives research and interventions by undergraduate students are beneficial to the PHC providers and communities. Graduate tracking is also essential to assess the number of healthcare workers who work in under-served communities or become physician scientists because of the Selectives.

In addition, precedence should be given to academic activities that integrate clinical activities and research into the curriculum, incorporate reflective learning, and create an awareness of a population perspective on clinical problems and the influence of the social determinants on health and disease, if UKZN is to meet its social accountability agenda.

\section{Ethical approval}

Ethical approval for the study was sought and obtained from the Biomedical Research Ethics Committee of UKZN (R201/04). 
Authors' contributions - SK is a public health physician and lecturer with overall responsibility for the Selectives Programme and coordinator of Selectives 1 as well as teaching a population perspective and public health competencies for undergraduate medical students at the Nelson R Mandela School of Medicine. AR is a family medicine specialist and lecturer responsible for coordinating Selectives 3. OM is a public health physician and lecturer responsible for coordinating Selectives 2 .

SK prepared the manuscript. AR and OM coordinated the teaching of the module in 2014 and 2015 and contributed to the writing of the article.

Acknowledgements - The authors wish to thank the students who evaluated this programme, the Selectives supervisors and site facilitators. Support from the UKZN Medical Education Partnership Initiative is gratefully acknowledged. Prof Steve Reid is acknowledged for his vision of setting up the initial Selectives initiative more than 10 years ago based on the communityoriented primary care approach.

\section{References}

1. Frenk J, Chen L, Bhutta Z, et al. Health professionals for a new century: transforming education to strengthen health systems in an interdependent world. Lancet. 2010;376(9756):1923-58. doi:10.1016/ S0140-6736(10)61854-5.

2. Gillam S, Maudsley G. Public health education for medical students: rising to the professional challenge. J Public Health (Bangkok). 2010;32(1):125-31. doi:10.1093/pubmed/fdp108.

3. Health Professions Council of South Africa. Medical and dental professions board: core competencies for undergraduate students in clinical associate, dentistry and medical teaching and learning programmes in South Africa. Pretoria: Author; 2014.

4. HPCSA College of Health Sciences Teaching and Learning Task Team. Core competencies for undergraduate students in the college of health sciences teaching and learning programmes at the university of KwaZulu-Natal. Durban: University of KwaZulu-Natal; 2015.

5. Manchanda R. The upstream doctors: medical innovators track sickness to its source. 2013. Available from: http://www.healthbegins.org/

6. Mayosi BM, Dhai A, Folb P. Consensus Report on Revitalising Clinical Research in South Africa a Study on Clinical Research and Related Training in South Africa. Pretoria: Academy of Science of South Africa; 2009. Available from: http://www.assaf.co.za/wp-content/ uploads/2009/09/ASSAf-Clinical-Report-2009.pdf.

7. Thompson N, Pascal J. Developing critically reflective practice. Reflective Pract. 2012;13(2):311-25. doi:10.1080/14623943.2012.657795.

8. Aukes LC, Geertsma J, Cohen-Schotanus J, et al. The effect of enhanced experiential learning on the personal reflection of undergraduate medical students. Med Educ Online. 2008;13:15. doi:10.3885/meo.2008.Res00279.

9. Engel $G$. The need for a new medical model:a challenge for biomedicine. Science. 1977;196(4286):129-36.

10. Woollard B, Boelen C. Seeking impact of medical schools on health: meeting the challenges of social accountability. Med Educ. 2012;46(1):21-7. doi:10.1111/j.1365-2923.2011.04081.x

11. Crawford R. Health as a meaningful social practice. Health (Irvine Calif). 2006;10(4):401-20.

12. Tollman S. The pholela health centre-the origins of communityoriented primary care (COPC). An appreciation of the work of Sidney and Emily Kark. S Afr Med J. 1994;84(10):653-8.

13. Geddes R, Giddy J, Butler LM, et al. Dual and triple therapy to prevent mother-to-child transmission of HIV in a resource-limited setting-lessons from a South African programme. S Afr Med J. 2011;101(9):651-4.

14. Kark S, Kark E. An alternative strategy in community health care: community-oriented primary health care. Isr J Med Sci. 1983;19(8):707-13.

15. Crouse Quinn S. Teaching community diagnosis: integrating community experience with meeting graduate standards for health educators. Health Educ Res. 1999;14(5):685-96.
16. Boelen C, Woollard B. Social accountability and accreditation: a new frontier for educational institutions. Med Educ. 2009;43(9):887-94. doi:10.1111/j.1365-2923.2009.03413.x.

17. Knight SE, Van Wyk JM, Mahomed S. Teaching research: a programme to develop research capacity in undergraduate medical students at the University of KwaZulu-Natal, South Africa. BMC Med Educ. 2016;16(1):12. doi:10.1186/s12909-016-0567-7.

18. National Department of Health. Standard treatment guidelines and essential medicines list: primary health care. Pretoria: National Department of Health; 2014. Available from: http://www.health.gov. za/index.php/component/phocadownload/category/197.

19. Littlewood S, Ypinazar V, Margolis SA, et al. Early practical experience and the social responsiveness of clinical education: systematic review. $\mathrm{Br}$ Med J. 2005;331:387-91. https://doi.org/10.1136/ bmj.331.7513.387

20. Woodward AJ. Public Health has no place in undergraduate medical education. J Public Health Med. 1994;16(4):389-92.

21. Strasser R, Couper I, Wynn-Jones J, et al. Education for rural practice in rural practice. Educ Prim Care. 2016;27(1):10-4. doi:10.1080/1473987 9.2015.1128684.

22. Reid SJ, Cakwe M, Chandia J, et al. The contribution of South African curricula to prepare health professionals for rural or underserved areas in South Africa: A peer review evaluation. S Afr Med J. 2011;101(1):34-8. http://dx.doi.org/10.7196/SAMJ.4526

23. Vieira JE. Directing student response to early patient contact by questionnaire. Med Educ. 2003;37(2):119-25. doi:10.1046/j.13652923.2003.01431.x

24. Dornan T. Osler, Flexner, apprenticeship and 'the new medical education'. J R Soc Med. 2005;98(3):91-5. doi:10.1258/jrsm.98.3.91.

25. Yardley S, Brosnan C, Richardson J, et al. Authentic early experience in Medical Education: a socio-cultural analysis identifying important variables in learning interactions within workplaces. Adv Heal Sci Educ. 2013;18(5):873-91. doi:10.1007/s10459-012-9428-2.

26. Imafuku R, Saiki T, Kawakami C, et al. How do students' perceptions of research and approaches to learning change in undergraduate research? Int J Med Educ. 2015;6:47-55. doi:10.5116/ijme.5523.2b9e.

27. Nel D, Burman RJ, Hoffman R, et al. The attitudes of medical students to research. S Afr Med J. 2014;104(1):32-6. doi:10.7196/SAMJ.7058.

28. Murdoch-Eaton D, Drewery S, Elton S, et al. What do medical students understand by research and research skills? identifying research opportunities within undergraduate projects. Med Teach. 2010;32(3):e152-e160. doi:10.3109/01421591003657493.

29. Oliveira CC, de Souza RC, Abe EHS, et al. Undergraduate research in medical education: a descriptive study of students' views. BMC Med Educ. 2013;14:51. doi:10.1186/1472-6920-14-51.

30. Abu-zaid A, Alkattan K. Integration of scientific research training into undergraduate medical education: a reminder call. Med Educ Online 2013;18(1):22832. doi:10.3402/meo.v18i0.22832.

31. De Haven M, Chen L. Teaching Medical Students Research While Reaching the Underserved. Fam Med. 2005;37(5):315-17.

32. Solomon SS, Tom SC, Pichert J, et al. Impact of medical student research in the development of physician-scientists. J Investig Med. 2003;51(3):149-56.

33. Fang D, Meyer R. Effect of Two Howard Hughes Medical Institute Research Training Programs for Medical Students on the Likelihood of Pursuing Research Careers. Acad Med. 2003;78(12):1271-80. doi:10.1097/00001888-200312000-00017.

34. Pruskil S, Burgwinkel P, Georg W, et al. Medical students' attitudes towards science and involvement in research activities: A comparative study with students from a reformed and a traditional curriculum. Med Teach. 2009;31(6):e254-e259. doi:10.1080/01421590802637925.

35. Boehme CC, Nicol MP, Nabeta P, et al. Feasibility, diagnostic accuracy, and effectiveness of decentralised use of the Xpert MTB/RIF test for diagnosis of tuberculosis and multidrug resistance: a multicentre implementation study. Lancet. 2011;377(9776):1495-505. doi:10.1016/S0140-6736(11)60438-8. 